\title{
What Consequences, in Relation to the Reforms in the Area of Law, Would the Deserved Expansion in the Study of the Field of Sociology of Law in Albania Bring?
}

\author{
Dr. Fatmir Zanaj \\ Department of Sociology, Faculty of Social Sciences, University of Tirana \\ Email: fzanaj@gmail.com
}

Doi:10.5901/ajis.2015.v4n2s2p163

\section{Introduction}

Paraphrasing A. Kronman's typology on different perspectives of legal studies based on Max Weber, the American sociologist Mathieu Deflem declares that "external perspectives of law engage in the theoretically driven empirical study of law to examine the characteristics of existing systems of law, including state and development, the causes and effects, and the functions and objectives of the institution and practices of law" (Deflem 2008, pp.4-5). As such the external perspectives of law comprise the subject matter of Sociology of Law. It makes the external sociological studies of law different from internal perspectives, which is a specialty of legal science - a range of disciplines being taught at law faculties that go hand in hand with practical training in law, as well.

Since 2007-2008 the socio-legal discipline has been included in the curricula of several Albanian law schools. The first textbook on this discipline in Albanian, named "Sociology of Law", was published in Tirana in 2010, and only a few months later, a similar text was also published in Kosovo. ${ }^{* 1}$ I think that the continued extension of the study of law from this socio-legal perspective will help greatly in preparing people, conditions, strategies, and measures for the successful implementation of current reforms in the justice system and for the future of its democratic effective functioning.

\section{Sociology of Law offers concepts and paradigms not sufficiently known by lawyers.}

In law faculties across Albania and Kosovo, students are focused to the study of legal texts and statutes. In several disciplines such as Criminal Law, Civil Law, Constitutional Law and so on, professors educated in law schools are pushing their students to focus mainly on the black and white letters of legal text, codes, procedural rules, constitutions, legal commentaries, unified decisions, etc., to reach the internal logic of the current law, supplemented in specific disciplines with the comparative textual or historical study of this logic. But one of the fathers of American jurisprudence, O.W. Holmes, stated that "For the rational study of the law the black letter man may be the man of the present, but the man of the future is the man of statistics and the master of economics". (Holmes, 2012, pp.20-21) These words were announced in 1897. Since the mid-50s of the last century W. O. Holmes' prophetic words were confirmed by life. By theoretical or general sociology of law, currently the balance is skewed in favor of empirical law, the empirical research on the behavior of judges, the legal consciousness of citizens, the functioning of the institutions of justice and the extralegal factors affecting the decision of the judges, etc.

Building on the ideas of the first sociologists who included the discipline of sociology of law in the curriculum of the St. Petersburg University for the first time in Europe at the beginning of the 20th century, the Pole Leon Petrazycki, modern sociology underline that:

Law is not only what is fixed in statutes, precedents and numerous legal traditions in each country. It is not necessarily enough to know only the formal sources of law, such as codes, statutes, precedents or traditions in a given society. It is necessary to go further, to know phenomena of consciousness and intuition, the legal consciousness of people. Hence, to explore a law's life in the way it exists or operates from the perspective of the participants in the legal process it is not enough to only apply logical analysis of legal rules. (See Zanaj 2011, p. 76).

* These textbooks are: Fatmir Zanaj, Sociologjia e së Drejtës,. "Naim" Publishing house, Tiranë 2010, and Prof. Dr. Beqir Sadikaj, Sociologjia e së Drejtës, Prishtina University Press, 2010. 
Sociology of law, compared to philosophy of law, better prepares and expands lawyers' outlook. In the preamble to the Attorney Ethics Code, two lines summarize the universally understood formation of lawyers, it is in the phrase: "Conscious of the role and duty of the lawyer in a democratic society based on the principles of the rule of law, humanism and human dignity, with respect to truth and justice, we state the Attorney Ethics Code" (K. E. A. 2005). While sociology of law, relying on the ideas of distinguished American sociologist Talcott Parsons, considers lawyers as "healers" of potential major diseases affecting the justice system, sociologically explaining their social position as a medium or mediator, who stands among the general public and client, between law and private client requests, and compares them to doctors. (See Zanaj 2010, p. 272) In the current conditions of our society, taking into account the necessity of involving lawyers in the struggle to heal our justice system from the disease of corruption, sociologists go further, and argue that the commitment of lawyers to the law should show the same devotion shown by doctors to patients, expressed at the Hippocrates Oath. (Zanaj 2015, pp. 51-52). From this sociological perspective and worldview we conclude that reforms in the area of justice cannot succeed without the active role of lawyers, without their awareness of the dangers that come to the system from the misunderstanding of their dual character as a medium of the legal profession, focusing specifically on the role of the lawyer, as a representative of the law and society, as well as a representative of the private interests of the client.

The researchers say that the identification of extralegal factors and their sociological testing on the impact of the justice system, especially in the operation of the judiciary, is a major project in the studies of sociology of law. (See Livermore 2010, p. 1192) In this list of "extralegal factors", sociologists of law include political, ideological, financial, ethnic, cultural, etc., factors affecting the functioning of the judiciary and distorting judicial decision. In our trials in Albania the influence of such factors on the decision of the judges is quite visible.

Sociology of law also provides lawyers with a view of the historic understanding of law. But this is done by avoiding the classic Marxist periodization in the study of law done through five socio-economic formations, and by studying the nature and functioning of law in three major historical periods - the pre-modern period, the modern and postmodern period.

While sciences on law provide students of law schools with instruments to logically study legal texts, inspire them with legal formalism, sociology of law provides lawyers with other important instruments - such as concepts, paradigms, and theories specific to this discipline. Legal sciences (juridical dogmatic study) do not have as their object and do not explain everyday behavior of judges during judicial proceedings. Meanwhile sociology of law provides them with a pluralism of explanations and theories in this regard as, for example, conflict theory, the behaviorist theory or that of symbolic interaction, with concepts borrowed from economics as well, as outlined in the works of Richard Posner and Gary Becker (Nobel Prize winner) from the Chicago School.

Sociology of law expands the universally understood formation of law students, because it studies the law and legal institutions using different paradigms of sociological perspective, as paradigm of conflict, that of realistic-critical, structuralist-functionalist paradigm, postmodernist paradigm etc., which are traditionally quite unknown in legal sciences. For example, according to realistic paradigm, strongly defended by Karl Llewellyn, the study of law is made according to factual descriptive approach, that focuses on the behavioral dimensions of law and distinction between the so-called "paper rules and rights" that are used in legal doctrine, and the "real rules and rights" that are conceived in terms of behavior. (Schauer 2013, pp. 750-751) Structuralist-functionalist paradigm, developed by Talcott Parsons, focuses on the view of society as a system, which is used to clarify how society can secure integration, particularly in the light of growing individualism. Use of this paradigm is interesting for the current conditions of the Albanian society.

\section{The scope of the study of sociology of law in Albanian universities today and the necessity of including this discipline in all law school curricula.}

The process of including sociology of law in university curricula in Albania started in the 2007-2008 school-years, almost half a century after the curricula of many American universities and Western Europe, as well as Poland.

This year the outline in public universities' curricula in our country is as follows:

- At the University of Tirana: Sociology of law is included in the Faculty of Social Science curriculum, Department of Sociology program. It takes place as electives, named "Legal Sociology", in the Faculty of Law.

- At the University "Alexander Moisiu" Durrës: Neither sociology of law nor philosophy of law are included in its curricula. It is mentioned elsewhere with the title "Legal Sociology" as an elective.

- At the University "Ismail Qemali" Vlorë: Neither sociology of law nor philosophy of law are included in its curricula. 
- At the University "Luigj Gurakuqi" Shkodër: Sociology of law, titled "Juridical Sociology" is included as an optional subject in the Faculty of Law.

The inclusion of the "Sociology of Law" in the curricula of nonpublic universities and high schools of our country this school-year is as follows:

- At the European University of Tirana: Sociology of law is included in the program at the "Master" level.

- At the "Luarasi" University: Sociology of law is included as an elective titled "Juridical Sociology".

- At the "Marin Barleti" University: In the Faculty of Law the subject "Sociology" is included, but not clarified if it relates to sociology of law.

- At the Tirana Business University: There is no place for sociology of law in the Faculty of Business Law.

- At the Albanian University of Tirana: Sociology of law is not included in the curriculum of the program "Legal Sciences".

- At the High School "Full Moon" (Beder): There is no place for sociology of law and philosophy of law in its curricula.

- At the Mediterranean University of Albania: Sociology of law, named "Legal Sociology", is included in the curriculum of the Faculty of Political Science and Law.

- At the University of New York in Tirana: Sociology of law is not included in its curriculum.

- At the high school "Wisdom University": Sociology of law is not included in its curriculum.

From a quick glance of this data you find that sociology of law has not occupied the place it deserves in the curricula of universities and high schools of our country. Even where it is accepted as electives, we have "alterations" in its name, sometimes called "Legal Sociology" and sometimes called "Juridical Sociology", indicating the presence of old prejudices of lawyers over the place and role of the discipline "Sociology of Law" in the curricula of law schools. Since the ancient Roman times when competition between philosophers and lawyers began, Roman jurists' contribution to the development of legal theory marked the beginning of a tradition of rivalry between legal professionals, on the one hand, and philosophers (later, in the 20th century, and sociologists) on the other hand, in the study of legal phenomena. In the US and Britain this rivalry appears today in the presence of movements such as "Law and Society" or "Law in Society", who try to push aside sociology of law, to interrupt genuine sociologists from the study of legal phenomena.

Even in the few Albanian universities and high schools where today the discipline "Sociology of Law" (or Legal Sociology, Juridical) is taught, teachers who lecture in these subjects are almost exclusively lawyers, without any scientific sociological training.

\section{Conclusions}

As in any investment in every sector of life, where investment in research and scientific approach of the project of facility occupies a significant place in the total of that investment, sociological studies of legal phenomena would help to successfully complete the current reforms in the Albanian justice system. These studies will serve as an important scientific basis for the work all state institutions, legislative and law enforcement agencies are making to address with greater competence successive suggestions and criticisms from the European Commission for the reformation of the Justice system, expressed in its progress reports on Albania from 2005 until 2015.

Second, the time has come to rid once and for all old prejudices in the Albanian terrain of science which undermine the importance and usefulness of Sociology, a prejudice which ruled for decades in Albanian communist education systems. This should be accompanied by the deserved expanding in curricula of all schools of Law, in public universities and in non-public, the discipline of sociology of law, which must be lectured by genuine sociologists, dealing in practice with the empirical and theoretical study of legal phenomena.

Ministry of Education and Sports should exercise control over the maintenance of the curricula in the faculties of Law in public schools as well as non-public schools, and require their involvement in the discipline of sociology of law.

\section{References}

Deflem, Mathieu, Sociology of Law. Visions of a Scholarly Tradition, Cambridge University Press 2008.

Holmes, Oliver Wendell, The Path of the Law, Applewood Books, Bedford Massachusetts.

Kodi Etik i Avokatit, - http://dhka.org.al/site-wp/?page_id=1093

Michael A. Livermore, Realist lawyers and realistic legalist: a brief rebuttal to judge Posner, Duke Law Journal, Vol. 59, 2010.

Schauer, Frederick, Legal Realism Untamed, Law Texas Review, vol. 91, 2013. 
Zanaj, Fatmir, Filozofia e së Drejtës, ShB. "Naim", Tiranë 2012.

Zanaj, Fatmir, "From Hippocrates to Talcott Parsons, - healing the "healers" to succeed in reforms in the area of justice", The Fourth International Scientific Conference "The State, Society and Law: Albanians 25 years from the change of systems", Abstract proceedings, vol IV, 2015.

Zanaj, Fatmir, Sociologjia e së Drejtës, ShB. "Naim”, Tiranë 2010. 